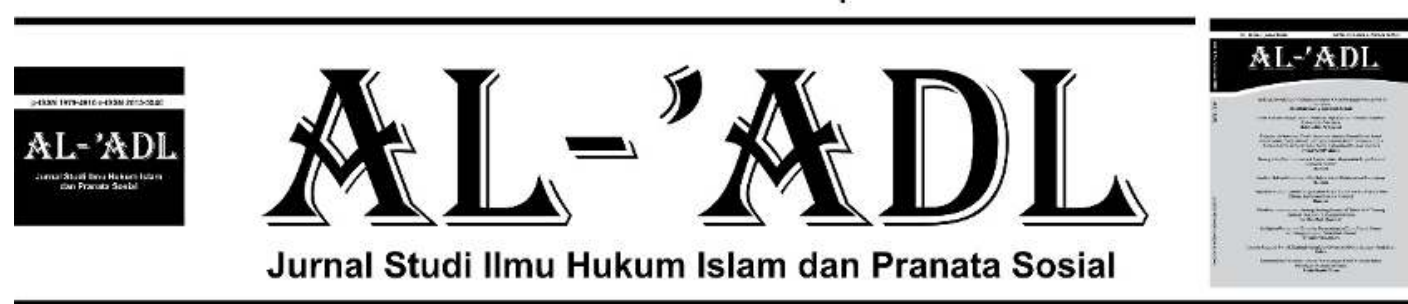

journal homepage : ejournal.iainkendari.ac.id/al-adl

\title{
The Dynamics Marriage Readiness of Muslim Adolescent from the Perspective of Psychology and Islamic Law
}

Eka Sufartianinsih Jafar ${ }^{1}$, Andi Yaqub ${ }^{2}$

${ }^{1}$ Fakultas Psikologi, Universitas Negeri Makassar, Indonesia

${ }^{2}$ Fakultas Syariah, Institut Agama Islam Negeri Kendari, Indonesia

E-mail: ekasjafar@unm.ac.id1 ${ }^{1}$ andiyaqub@,iainkendari.ac.id ${ }^{2}$

\section{ARTICLE INFO}

Article History :

Received: 2021-06-23

Accepted: 2021-06-24

Published: 2021-07-31

Keywords: Adolescent, Islamic Law, Marriage, Premarital, Psychology

(C) Year Al-'Adl. All rights reserved

\section{ABSTRACT}

The high rate of divorce in young couples is motivated by psychological and spiritual unpreparedness. Premarital education is a resolution to minimize the divorce rate. This study aims to hack the knowledge and understanding of Muslim adolescents regarding marriage and marriage readiness from a psychology and Islamic law perspective. This type of research uses a descriptive quantitative data collection method using a survey in the form of a questionnaire. The research subjects were 820 adolescents aged 15-20 years who came from various levels of education, namely senior high school students (54.5\%) and undergraduate students $(45.5 \%)$. The results of this study indicate that there are several motivations for marriage for Muslim adolescents, namely (1) wanting to justify themselves by $49 \%$ (2) wanting to get attention and affection by $20.5 \%$, (3) wanting to have children by $15.6 \%$, (4) improve the economy by $10 \%$, (5) follow parents wishes $4.9 \%$. While the things that teenagers need to prepare for marriage are (1) Economy by 31.9\%, (2) Studying Religion by $29.4 \%$, (3) Education by $20.7 \%$, and (4) Improving Character 18\%. Adolescent understanding is still low on the purpose of marriage and the forms of marriage readiness. Indicated by the orientation and motivation of marriage is dominated by the fulfillment of biological and material needs. The implication of this research is to be able to 
provide a comprehensive view in terms of marriage readiness from the point of view of psychology and Islamic law as reference material for providing premarital preparation/premarital education to adolescents so that they can prepare for married life.

\begin{abstract}
ABSTRAK
Tingginya tingkat perceraian pada pasangan muda dilatarbelakangi ketidaksiapan secara psikologis dan spiritual. Edukasi pra nikah merupakan resolusi meminimalisir tingkat perceraian. Penelitian ini bertujuan untuk meretas pengetahuan dan pemahaman remaja muslim terkait pernikahan dan kesiapan menikah ditinjau dari sudut pandang psikologi dan hukum Islam. Jenis penelitian ini menggunakan kuantitatif deskriptif dengan metode pengumpulan data menggunakan survei dalam bentuk kuesioner. Subjek penelitian yakni 820 remaja berusia 15-20 tahun yang berasal dari berbagai jenjang pendidikan yaitu SMA/SMK $(54,5 \%)$ dan mahasiswa S1 $(45,5 \%)$. Hasil penelitian ini menunjukkan bahwa terdapat beberapa motivasi menikah bagi remaja muslim, yaitu (1) ingin menghalalkan diri sebesar $49 \%$ (2) ingin mendapatkan perhatian dan kasih sayang sebesar $20,5 \%$, (3) ingin memiliki anak sebesar $15,6 \%$, (4) memperbaiki ekonomi sebesar $10 \%$, (5) mengikuti keinginan orangtua $4,9 \%$. Sedangkan hal yang perlu dipersiapkan remaja untuk pernikahan (1) Ekonomi sebesar 31,9\%, (2) Mendalami Agama sebesar 29,4\%, (3) Pendidikan 20,7\%, dan (4) Memperbaiki Karakter 18\%. Pemahaman remaja masih rendah terhadap tujuan pernikahan dan bentukbentuk kesiapan menikah. Ditunjukkan dengan orientasi dan motivasi menikah didominasi oleh pemenuhan kebutuhan biologis dan materil. Implikasi dari penelitian ini agar dapat memberikan pandangan yang komprehensif dalam hal kesiapan menikah dari sudut pandang psikologi dan hukum Islam sebagai bahan acuan untuk memberikan premarital preparation/edukasi pranikah pada remaja agar mampu mempersiapkan diri menjalani kehidupan pernikahan.

Kata Kunci: Pranikah, Remaja, Pernikahan, Psikologi, Hukum Islam
\end{abstract}

\title{
A. INTRODUCTION
}

Each individual has a developmental task that must be passed based on his age ranging from childhood, adolescence, adults, to the elderly. In each phase of human development has its developmental tasks that must be achieved to achieve satisfaction and happiness in his life, and support the achievement of the development task in the next phase. The adolescent phase is a phase of rapid 
physical change and sexual maturity. ${ }^{1}$ This contributes to teenagers who begin to feel an attraction to the opposite sex and have close friends such as girlfriends. The results of 2017 Indonesian Demographic and Health Survey (SKDI) showed that the vast majority of teenage girls $(81 \%)$ and teenage boys $(84 \%)$ have been dating. 45 percent of teenage girls and 44 percent of teenage boys indicate that adolescents are dating at the age of 15 to 17 years. ${ }^{2}$ The age of 15 to 17 years is the final teenage phase where most teenagers date.

The late teenage phase is the last stage before entering adulthood. Luella Cole classified adolescent developmental tasks into nine categories: emotional self-esteem, stabilization of heterosexual interests, social maturity, emancipation from family control, intellectual maturity, choosing work. using leisure time appropriately, having a philosophy of life, self-identification. ${ }^{3}$ Based on the task of development shows that the establishment of sexual interests with the opposite sex needs to get special education and assistance agar there is no violation of religious norms and norms that apply in society.

Teenagers are individual prospective couples who will later build a family and become prospective parents for children born, so there needs to be preparation and planning to support marriage readiness. Readiness to marry is the key to the establishment of family resilience and quality families are expected to be able to give birth to a quality generation. ${ }^{4}$

The transition from adolescence to adulthood is characterized by continuous conflict. Early adulthood is a period of searching, discovery, stabilization, and

\footnotetext{
${ }^{1}$ Khamim Zarkasih Saputro, "Memahami Ciri dan Tugas Perkembangan Masa Remaja", Aplikasia: Jurnal Aplikasi Ilmu-Ilmu Agama, Vol. 17, No. 1, February 9, 2018): 25-32.

${ }^{2}$ Siaran Pers BKKBN, "Kesehatan Reproduksi Dan Pernikahan Dini," BKKBN, December 8, 2019, https://www.bkkbn.go.id/detailpost/kesehatan-reproduksi-dan-nikah-dini. https://books.google.co.id/books?id=5KRPDwAAQBAJ.

(Kencana, n.d.),

${ }^{4}$ BKKBN, "Kesehatan Reproduksi Dan Pernikahan Dini."
} 
reproductive times, a time filled with emotional problems and tensions, periods of social isolation, periods of commitment and dependency, changes in values, creativity, and adjustment to the new life. ${ }^{5}$ Finding a partner and getting married is one of the important developmental tasks to accomplish in early adulthood. adolescent development tasks,

Hurlock divides the tasks of early adult development, namely as follows: (a) Getting a job; (b) choose a life friend; (c) learn to live together with the husband and wife to form a family; (d) raising children; (e) manage a household; (f) accept responsibility as a citizen; $(\mathrm{g})$ join a social group. ${ }^{6}$ This shows the importance of preparing to enter the task of early adult development, namely finding a partner, getting married, and building a family considering that marriage is a complex process that requires physical, mental, material, psychological, and spiritual readiness. The earlier the readiness to marry, the more ready the individual will be to face. ${ }^{7}$ This is the basis of this study which aims to find out indicators of marriage readiness in late adolescence.

Late adolescence as a transition age needs to have awareness, knowledge, and preparation ahead of adulthood, one of which is the readiness to marry. Readiness to marry is one of the factors that can reduce the risk of divorce, ${ }^{8}$ and can achieve marital satisfaction and well-being. ${ }^{9}$ Duvall and Miller suggest that getting married is a state of being ready or willing to connect with a partner, ready

5 Alifia Fernanda Putri, "Pentingnya Orang Dewasa Awal Menyelesaikan Tugas Perkembangannya," SCHOULID: Indonesian Journal of School Counseling 3, no. 2 (June 21, 2018): 35 .

${ }^{6}$ Elizabeth B Hurlock, Psikologi Perkembangan (Jakarta: Erlangga, 1980).

${ }^{7}$ J. S. Carroll et al., "Ready Or Not? Criteria For Marriage Readiness Among Emerging Adults," Journal of ... (2009), https://journals.sagepub.com/doi/abs/10.1177/0743558409334253.

${ }^{8}$ Yunita Sari, Andhita Nurul Khasanah, and Sarah Sartika, "Studi Mengenai Kesiapan Menikah Pada Muslim Dewasa Muda," Prosiding SNaPP: Kesehatan (Kedokteran, Kebidanan, Keperawatan, Farmasi, Psikologi) 2, no. 1 (2016): 193-204.

9 Thomas B Holman and Bing Dao Li, "Premarital Factors Influencing Perceived Readiness For Marriage,” Journal of Family Issues 18, no. 2 (1997): 124-144. 
to accept responsibilities as a husband or wife, ready to engage in sexual relations, ready to organize a family, and ready to raise children. ${ }^{10}$ People's expectations about independence are still assessed by economic and social status, so the measure of readiness is measured from the financial and strata in society. ${ }^{11}$

Research conducted by Sari and Sunarti involving 115 early adult students showed that there are factors of readiness to marry according to early adulthood are emotional readiness (controlling emotions and empathy ability), social (social skills, social cognition, and tolerance), roles, communication skills, age, financial, and sexual. The results of the study also showed differences in marriage readiness between men and women. The most important factor of marriage readiness for men is financial readiness and for women is emotional readiness. The results of the study are drawn in the following table: ${ }^{12}$

Table 1. Results of Waiting for the Order of Readiness Factors for Married Students

\begin{tabular}{lcc}
\hline $\begin{array}{l}\text { The readiness factor of } \\
\text { marriage }\end{array}$ & Men (\%) & Women (\%) \\
\hline Financial readiness & 100,0 & 45,4 \\
\hline Emotional readiness & 85,4 & 84,5 \\
\hline Role readiness readiness & 62,8 & 53,6 \\
\hline $\begin{array}{l}\text { Physical } \\
\text { (healthy) }\end{array}$ & 29,1 & 29,1 \\
\hline Spiritual readiness & 28,2 & 20,9 \\
\hline Social readiness & 12,7 & 17,3 \\
\hline Sexual readiness & 7,3 & 25,4 \\
\hline Age readiness & 1,8 & 1,8 \\
\hline $\begin{array}{l}\text { Communication skills } \\
\text { not yet measured) }\end{array}$ & 0,0 & 0,0 \\
\hline
\end{tabular}

${ }^{10}$ David H Olson and John DeFrain, Marriages And Families: Intimacy, Diversity, And Strengths (McGraw-Hill US Higher Ed USE, 2013).

${ }^{11}$ Andi Yaqub, Iswandi Iswandi, and Jabal Nur, "Reconstruction of Sakīnah Family Criteria During the Covid-19 Period," Al-Ahkam 31, no. 1 (April 29, 2021): 1-24. Muslims."

${ }^{12}$ Sari, Khasanah, and Sartika, "The Study of Marriage Readiness in Young Adult 
The readiness of marriage is assumed to be more thought of by individuals in early adulthood, but the short period of transition from late adolescence to early adulthood makes the need for late adolescence to start thinking about and preparing for their future, one of which is the readiness to build marriage and family relationships.

The high rate of divorce in young couples is motivated by psychological and spiritual unpreparedness. Premarital education is a resolution to minimize the divorce rate. This research aims to hack the knowledge and understanding of Muslim adolescents related to marriage and marriage readiness gave psychology and Islamic law. Even data from the Director-General of Islamic Society of the Ministry of Religious Affairs shows that out of 2 million marriages there are 300,000 divorce cases occur every year. ${ }^{13}$ The anomaly of marriage and divorce is also poured from sirri marriage which is dominated by the unpreparedness of couples both juridically and socioeconomically. ${ }^{14}$ This condition shows a critical phase in the process of preparing for marriage among the community, especially Muslim teenagers.

The Industrial Revolution 4.0 negatively impacted social life, particularly the family as the smallest social unit. Family unpreparedness in the face of Volatile, Uncertainty, Complexity, Ambiguity (VUCA) will give birth to a broken family (saturated family). Families also face an expansion of vulnerabilities and potential crises and quality of life disorders. ${ }^{15}$

${ }^{13}$ CNN Indonesia, "Catatan Kemenag: Rata-Rata 300 Ribu Perceraian Tiap Tahun," CNN Indonesia, n.d., accessed March 3, 2021, https://www.cnnindonesia.com/nasional/2020121811325120-583771/catatan-kemenag-rata-rata-300-ribu-perceraian-tiap-tahun.

${ }^{14}$ Ashadi L Diab, "Legalisasi Nikah Sirri Melalui Isbat Nikah Perspektif Fikih (Telaah Terhadap Kompilasi Hukum Islam)," Al-'Adl 11, no. 2 (2018): 36-61.

${ }^{15}$ Indonesian Media, "Professor of IPB: Every 1 Hour, There are 50 Divorce Cases in Indonesia," Indonesian media (Jakarta, April 7, 2021), Humaniora edition, accessed April 7, 2021, 
Based on the results of preliminary data taken on this study in 2021, showed that 35 percent of teenagers in South Sulawesi already have a girlfriend. From a psychological perspective, finding a partner is one of the developmental tasks of early adulthood that Erikson says is a time of intimacy versus isolation. ${ }^{16}$ Therefore, individuals in early adulthood will think more and seek information about the readiness of marriage, but the openness of information is inversely proportional to the level of understanding of adolescents. Low awareness related to the practice of Islamic values encourages the occurrence of association or interaction between adolescents out of control or not by the association in sharia. This is also shown by the orientation and motivation of marriage dominated by the fulfillment of biological and material needs.

This fact encourages researchers to conduct, research on the dynamics of Muslim adolescent marriage readiness is still needed so that late teens can realize the importance of premarital preparation so that teenagers can better prepare themselves in wading through the household ark. This research involves a review of Psychology and Islamic Law so that there is a comprehensive view in discussing and reviewing marriage readiness.

\section{B. METHODS}

This type of research uses descriptive quantitative research. The method of collecting data using the survey method using questionnaires distributed through google form with questionnaire links is https://forms.gle/T2LdTDwqunakqSQB9. Data collection is carried out for 1 week from February 24, 2021, to March 1, 2021. The subjects of the study were 820 late-Muslim adolescents aged 15-20

\footnotetext{
https://mediaindonesia.com/humaniora/416363/guru-besar-ipb-setiap-1-jam-terdapat-50-kasusperceraian-di-indonesia.

${ }^{16}$ J.W. Santrock, C.J. Mondloch, and A. Mackenzie-Thompson, Essentials of Life-Span Development (McGraw-Hill Education, 2020), https://books.google.co.id/books?id=MXiJzgEACAAJ.
} 
years who came from various levels of education, namely high school and vocational school, as well as undergraduate and D-III students. The research was conducted in several districts/cities in South Sulawesi Province.

\section{RESULTS AND DISCUSSIONS}

The data collection showed a distribution of study subjects, namely from 820 subjects, 25.5 percent were male and 74.8 percent were female. The level of education from the subject is 50.1 percent are high school students, vocational students 4.4 percent, and 45.5 percent status as students. The distribution of the subject is described in table 2 below:

Table. 2 Distribution of Research Subjects

\begin{tabular}{ccc}
\hline $\begin{array}{c}\text { Characteristics of } \\
\text { the Subject }\end{array}$ & $(\%)$ \\
\hline Gender & Man & 25,5 \\
& Woman & 74,8 \\
\hline Level of Education & SMA & 50,1 \\
& SMK & 4,4 \\
& Student & 45,5 \\
\hline
\end{tabular}

The results showed that there are several motivations for marriage in late teens, namely (1) Wanting to Justify Yourself because they love a partner, (2) want to get attention and affection, (3) want to have children, (4) want to improve the economy, and (5) Follow parental choices. Marriage is a legal procession recognized by religion and the state. Marriage is done by someone with a variety of goals or motivations. From a psychological review, the motivation of marriage is influenced by personal characteristics and marital experiences of the surrounding environment such as parents and other figures that are important to the individual. The motivation to marry can be motivated by emotional factors such as love, as well as affection factors such as wanting to be noticed and get affection, even the feeling of wanting to have a partner. In addition to emotional factors and sexual attraction factors also contribute to encouraging individuals to marry. 
The motivation to marry is among them as an effort to minimize relationships that are not by sharia, namely adultery. This social pathology is considered commonplace among Muslim teenagers as Islamic values and customs erode. Islam and customs in Islamic law as a whole unity as stated in the kubra rule that customary as one of the foundations in the establishment of Islamic law). The unity can be seen from the basic principles of society that uphold shame or siri'. Shame in Islam is part of the faith (الإيما من الحياء). Among the purposes of marriage is to pass on the generation (hifz nasab) is also a motivation for Muslim teenagers.

Table 3. Research Results

\begin{tabular}{lll}
\hline \multicolumn{1}{c}{ Survey Results } & & $(\%)$ \\
\hline Having a Girlfriend & Already & 35,0 \\
\cline { 2 - 3 } & Do not & 65,0 \\
\hline Readiness to Marry & Very Ready & 2,5 \\
\cline { 2 - 3 } & Ready & 5,0 \\
\cline { 2 - 3 } & Just ready & 5,6 \\
\cline { 2 - 3 } & Less Prepared & 23,5 \\
\cline { 2 - 3 } & Very Unprepared & 65,6
\end{tabular}

\begin{tabular}{ll}
\hline Motivation to marry & $\begin{array}{l}\text { Want to justify yourself and love } \\
\text { your partner }\end{array}$ \\
$\begin{array}{ll}\text { I want attention and affection. } \\
\end{array}$ & 20,5 \\
\hline Want to have children & 15,6 \\
\hline Want to fix the economy & 10,2 \\
\hline Following parental choices
\end{tabular}

4,7

\begin{tabular}{lll}
\hline Preparing teenagers for marriage & Economics & $31,9 \%$ \\
\cline { 2 - 3 } & Explore religion as much as & $29,4 \%$ \\
\cline { 2 - 3 } & Education & $20,7 \%$ \\
\cline { 2 - 3 } & Fixing Character & $18 \%$
\end{tabular}


The results of the study in terms of the readiness of married late Muslim teenagers can be seen in the table above, $65.7 \%$ of adolescents stated not ready to marry, $23.5 \%$ less ready to marry, quite ready $5.5 \%$, ready $5.1 \%$, and only $2.5 \%$ of teenagers who said they are very ready to marry. Readiness to marry an individual decision against him to marry. The majority of late teens in South Sulawesi who were respondents in the study still felt unprepared and unprepared to marry, even only 2.5 to 5.1 percent of late teens felt ready to marry.

Readiness to marry when viewed from a psychological point of view, namely the existence of age readiness is closely related to the improvement of empathy, communication skills, sexual readiness, and financial readiness. Although age is not a guarantee of mature empathy and regulation of one's emotions, age is considered a predictor of marriage readiness, the higher the readiness of age, the faster the marriage. People who are mature enough will be seen as more financially prepared, communication and empathy will also be better, and the more someone is ready to have sex. ${ }^{17}$

The amendment of Law No. 1 of 1974 on Marriage to Law No. 16 of 2019on Marriage, has listed the minimum age of marriage from 16 years for women to 19 years. The age range studied showed a tendency for the decision to marry over the age of 20 with various considerations. But those who choose to marry at an early age in addition to religious considerations are also economic considerations.

In terms of the preparation required to have a harmonious marriage, according to the subject, the greatest are (1) Economics, (2) Deepening Religion, (3) Education, and (4) Improving Character. The results if in the perspective of psychology, the preparation needed to marry is very related to the role to be lived, Muslims."

${ }^{17}$ Sari, Khasanah, and Sartika, "The Study of Marriage Readiness in Young Adult 
for example as a man who will later become the head of the family then understanding of religion, the ability to be a leader for the wife, and the ability to make a living is an important preparation, while for women who will become mothers emotional skills and the ability to manage the household and educate children is an important preparation.

The conception formulated by Hurlock states that the readiness of marriage is also closely related to the adjustment of the individual to the environment, scope, role, and new responsibilities he or she faces. This phase in South Sulawesi is in the form of values contained in Islamic law and community habits have accommodated various forms of new family habituation. This can be found in the procession of silaturrahim between the families and relatives of each couple, even the tradition of visiting ancestral tombs as a form of nasab recognition and respect.

The role undertaken by married couples and wives proportionally has also existed in Islamic teachings and customs. So that individual and social readiness are not separate. Husband as family leader and wife as a household leader. Both have duties and roles that are bound together, especially survival and guarantee of the future for children. The readiness of marriage in Muslim adolescents takes precedence over the clarity of life orientation, understanding and practice of Islamic values, as well as customs before marriage and while undergoing the ark of the household. Hope comes from a family of sakinah, mawaddah, and rahmah can be fulfilled.

\section{CONCLUSION}

The preparation of teenage marriage only includes the motivation of marriage that only focuses on fulfilling biological and material needs, has not been able to interpret marriage as a whole and deep as a form of fulfilling hopes to 
become a family sakinah, mawaddah, and rahmah. The fallacy in outlook on life and low understanding and awareness of Islamic values and customs are the main culprits. This study has not explored the values of customs comprehensively both psychological review and Islamic law related to the readiness of marriage. So that the object of this study still has a large observation room. The use of more detailed quantitative or qualitative methods through the analysis of factors from questionnaire items can be developed, by doing so on respondents from other demographic regions and in different age groups and genders.

\section{REFERENCES}

\section{Books}

Hurlock, Elizabeth B. Psikologi Perkembangan. Jakarta: Erlangga, 1980.

\section{Journal}

Carroll, J. S., S. Badger, B. J. Willoughby, and ... "Ready Or Not? Criteria For Marriage Readiness Among Emerging Adults." Journal of ... (2009). https://journals.sagepub.com/doi/abs/10.1177/0743558409334253.

Diab, Ashadi L. "Legalisasi Nikah Sirri Melalui Isbat Nikah Perspektif Fikih

(Telaah Terhadap Kompilasi Hukum Islam)." Al-'Adl 11, no. 2 (2018): 3661.

Holman, Thomas B, and Bing Dao Li. "Premarital Factors Influencing Perceived Readiness For Marriage." Journal of Family Issues 18, no. 2 (1997): 124 144.

Olson, David H, and John DeFrain. Marriages And Families: Intimacy, Diversity, And Strengths. McGraw-Hill US Higher Ed USE, 2013.

Putri, Alifia Fernanda. "Pentingnya Orang Dewasa Awal Menyelesaikan Tugas Perkembangannya." SCHOULID: Indonesian Journal of School Counseling 3, no. 2 (June 21, 2018): 35.

Saputro, Khamim Zarkasih. "Memahami Ciri Dan Tugas Perkembangan Masa Remaja." Aplikasia: Jurnal Aplikasi Ilmu-ilmu Agama 17, no. 1 (February 9, 2018): 25-32. 
Sari, Yunita, Andhita Nurul Khasanah, and Sarah Sartika. "Studi Mengenai Kesiapan Menikah Pada Muslim Dewasa Muda." Prosiding SNaPP: Kesehatan (Kedokteran, Kebidanan, Keperawatan, Farmasi, Psikologi) 2, no. 1 (2016): 193-204.

Yaqub, Andi, Iswandi Iswandi, and Jabal Nur. "Reconstruction of Sakīnah Family Criteria During the Covid-19 Period." Al-Ahkam 31, no. 1 (April 29, 2021): $1-24$.

\section{Internet}

BKKBN, Siaran Pers. "Kesehatan Reproduksi Dan Pernikahan Dini.” $B K K B N$, December 8, 2019. https://www.bkkbn.go.id/detailpost/kesehatanreproduksi-dan-nikah-dini.

Indonesia, CNN. "Catatan Kemenag: Rata-Rata 300 Ribu Perceraian Tiap Tahun." CNN Indonesia, n.d. Accessed March 3, 2021.

https://www.cnnindonesia.com/nasional/20201218113251-20-

583771/catatan-kemenag-rata-rata-300-ribu-perceraian-tiap-tahun.

Indonesia, Media. "Guru Besar IPB: Setiap 1 Jam, Terdapat 50 Kasus Perceraian Di Indonesia.” Media Indonesia. Jakarta, April 7, 2021, Humaniora edition. Accessed April 7, 2021. https://mediaindonesia.com/humaniora/416363/guru-besar-ipb-setiap-1jam-terdapat-50-kasus-perceraian-di-indonesia.

Jahja, Y. Psikologi Perkembangan. Kencana, n.d. https://books.google.co.id/books?id=5KRPDwAAQBAJ.

Santrock, J.W., C.J. Mondloch, and A. Mackenzie-Thompson. Essentials of LifeSpan Development. McGraw-Hill Education, 2020. https://books.google.co.id/books?id=MXiJzgEACAAJ. 